\title{
INTEREST GROUPS
}

\section{Wednesday, April 30, 2003, 1:00 - 4:30 PM}

IW1

Teaching Scholarship Interest Group

Session Coordinator: Sameh Basta, MD, Assistant Professor of Medicine, Eastern Virginia Medical School

IW2

Women's Caucus

Session Coordinator: Jennifer Zebrack, MD, Assistant Professor, Division of Internal Medicine, Medical College of Wisconsin

IW3

GIM Fellows Forum

Session Coordinator: Emran Rouf, MD, GIM Fellow, New York University

IW4

Anticoagulation-Thromboembolism Interest Group

Session Coordinator: Richard White, MD, Professor of Medicine, University of California, Davis

IW5

Cross-Cultural Communication and Medical Care Interest Group

Session Coordinator: Michael Nathan, MD, Assistant in Medicine, Instructor in Medicine, Massachusetts

General Hospital, Harvard Medical School

IW6

Minorities in Medicine Interest Group

Session Coordinator: Valerie Stone, MD, MPH, Associate Chief, General Medicine Unit, Massachusetts General Hospital

IW7

Gay and Lesbian Health Interest Group

Session Coordinator: Donald Brady, MD, Associate Professor of Medicine, Emory University

IW8

Geriatrics Interest Group

Session Coordinator: Glenda Westmoreland, MD, MPH, Indiana University School of Medicine

IW9

Homeless Healthcare Interest Group

Session Coordinator: David Buchanan, MD, Assistant Professor of Medicine, Cook County Hospital, Rush University

IW 10

International Medical Graduates (IMGs) and SGIM: Partnership for Success

Session Coordinator: Shakaib Rehman, MD, FACP, Assistant Professor of Medicine, Ralph H. Johnson VA Medical Center, Medical University of South Carolina

IW 11

Pain Medicine Interest Group

Session Coordinator: Daniel Alford, MD, MPH, Assistant Professor of Medicine, Boston University School of Medicine

IW12

Complementary and Alternative Medicine Interest Group

Session Coordinator: Bennett Lee, MD, MPH, Clinical Instructor, Emory University 
IW13

Health Policy Interest Group

Session Coordinator: David Calkins, MD, MPP, Associate Dean for Clinical Programs, Harvard Medical School

IW 14

Educators of Medical Students Interest Group

Session Coordinator: Shalini Reddy, MD, Assistant Professor of Clinical Medicine, University of Chicago

IW 15

Medicine and the Media Interest Group

Session Coordinator: Raymond Hobbs, MD, FACP, Associate Program Director, Oakwood Hospital and Medical Center

IW16

Primary Care Program Directors Interest Group

Session Coordinator: Carol Bates, MD, Primary Care Program Director, Assistant Professor, Beth Israel

Deaconess Medical Center, Harvard Medical School

IW 17

Web-Based Clinical Curriculum

Session Coordinator: Henry Sakowski, MD, Assistant Professor, Creighton University

IW18

Ethics Interest Group

Session Coordinator: Alexia Torke, MD, Assistant Professor, Emory University School of Medicine

IW19

Mental Health in Primary Care Interest Group

Session Coordinator: Caroline Doebbeling, MD, MSc, Assistant Professor of Internal Medicine, Psychiatry and

Epidemiology, University of Iowa's College of Medicine and College of Public Health

IW20

Research on Careers Interest Group

Session Coordinator: Mark Linzer, MD, Professor of Medicine, Chief, Section of General Internal Medicine, University of Wisconsin, Madison

IW2 1

Trans-Pacific Initiative in the Research and Teaching of General Internal Medicine/Primary Care

Session Coordinator: Shunzo Koizumi, MD, FACS, Professor and Chair, Department of General Medicine, Saga Medical School, Japan

Friday, May 2, 2003, 7:00 - 8:30 AM

IF 1

Academic Physician Administrators and Leaders

Session Coordinator: David Fairchild, MD, MPH, Director, Primary Care Services and Assistant Professor of Medicine, Brigham and Women's Hospital, Harvard Medical School

IF2

Substance Abuse Task Force

Session Coordinator: David Fiellin, MD, Associate Professor of Medicine, Yale University School of Medicine

IF3

Personal-Professional Balance Interest Group

Session Coordinator: Katharine Bradley, MD, MPH, Associate Professsor of Medicine, University of Washington VA Puget Sound 


\section{IF4}

Obstetric Medicine: Medical Disorders in Pregnancy

Session Coordinator: Sonya Vora, DO, Assistant Clinical Professor of Medicine and Obstetrics UMDNJ - Robert

Wood Johnson Medical School

IF5

Environmental Issues for the General Internist

Session Coordinator: Thomas Comerci, MD, Fellow in Primary Care, New York University

IF6

End-of-Life Interest Group

Session Coordinator: Mark Hughes, MD, Assistant Professor of Medicine, Johns Hopkins University School of Medicine

IF7

AIDS Task Force and HIV Interest Group

Session Coordinator: James Sosman, MD, Chair, AIDS Task Force, Associate Professor of Medicine, University of Wisconsin

IF8

Clinical Examination Research Interest Group

Session Coordinator: David Simel, MD, MHS, Associate Chief of Staff Ambulatory Care, Professor of Medicine, Durham VA Medical Center, Duke University

IF9

Academic General Internal Medicine in Latin America

Session Coordinator: Eliseo Pérez-Stable, MD, Professor University of California, San Francisco

IF 10

Asian Pacific Islander Interest Group

Session Coordinator: Navneet Kathuria, MD, MPH, Associate Chief, Division of General Medicine, St. Luke's-

Roosevelt Hospital Center

IF 11

Social Responsibility Interest Group

Session Coordinator: Oliver Fein, MD, Professor of Clinical Medicine and Public Health, Associate Dean, Weill Medical College of Cornell University

IF 12

Changing the 'Hidden Curriculum' to Promote Professional Values

Session Coordinator: Paul Haidet, MD, MPH, Staff Physician, Assistant Professor of Medicine, Houston VA Medical Center, Baylor College of Medicine

IF 13

Physicians Against Violence

Session Coordinator: Joslyn Fisher, MD, Assistant Professor of Medicine, Baylor College of Medicine

IF 14

International Health Special Interest Group

Session Coordinator: John Peabody, MD, DTM\&H, MPhil, PhD, FACP Deputy Director, Institute for Global Health, University of California, San Francisco, San Francisco VA Medical Center

IF 15

Women's Health Education Interest Group

Session Coordinator: Rebecca Brienza, MD, MPH, Assistant Professor, Yale University 
IF 16

Professionalism: Issues in Education and Evaluation

Session Coordinator: Michelina Fato, MD, Associate Program Director, Western Pennsylvania Hospital

Additional Faculty: Mary Wurm-Schaar, PhD, Curriculum Consultant, Western Pennsylvania Hospital

IF 17

Medical Resident Clinic Directors' Interest Group

Session Coordinator: Jeffrey Wong, MD, Associate Clinical Professor of Medicine, Yale University School of Medicine

IF 18

Medical Consultation/Perioperative Medicine

Session Coordinator: Steven Cohn, MD, Chief, Division of General Internal Medicine, Director, Medical Consultation Service, Clinical Associate Professor of Medicine, State University of New York Downstate Medical Center

IF 19

Evidence-Based Medicine Interest Group

Session Coordinator: Brent Williams, MD, MPH, Associate Professor, University of Michigan

IF20

Resident and Student Interest Group

Session Coordinator: Donald Brady, MD, Associate Professor, Emory University

IF2 1

The Role of Spirituality in Health

Session Coordinator: Christina Puchalski, MD, Director, The George Washington Institute for Spirituality and Health 